XXXI.-Extracts from the Minute Book of the Geological Society.

1809, April 7.

A notice respecting the Mucrus Mine, Killarney, by Mr. Wright, communicated by Dr. Babington, was read.

The Mucrus Mine was worked for about five years (from 1749 to 1754) to great advantage; the depth was then thirty-six fathoms, but the part of the vein within reach of the first shaft having become too narrow to pay for the expense of a second, it was determined to sink some distance to the east in the direction of the vein, which was thus recovered at the depth of from seventeen to twenty fathoms. It yielded yellow copper ore, and was five feet wide; the ore however being too sulphureous it was abandoned, though the original shaft had brought in $£ 30,000$, and was so easily drained that a common windlass kept it dry. The cobalt being totally unknown, except to a single adventurer (who on one occasion took away about twenty tons) was neglected, and landed only as rubbish, till a more experienced miner, since dead, at last pointed out its nature and value. From that time people visiting the mine have carried off specimen after specimen, so that the original profusion would now be doubtful, were not these circumstances recollected by most persons then resident in the neighbourhood. The ore has a granulated and metallic appearance; it has the hardness of stone; its colour is dark blue, tending to a beautiful pink. A mass of about a quarter of a hundred weight had the appearance of being found 


\section{Extracts from the Minute Book of the Geological Society.}

within the copper of the vein ; but this was only conjecture, for in whatever quantity it might then have been encountered, it was avoided as much as possible, and the many tons landed were removed as rubbish to make way for the miners. One great cause of the abandonment of the mine was the pecuniary difficulty occasioned by the war. Commercial intercourse, particularly the high insurance to Bristol, was too expensive for the then state of the mine, viz. working upon a new and shallow part of the vein. Since that period lands having risen much in value, the proprietors have been unwilling to injure the surface of their grounds by the admission of workmen who might trespass upon and disfigure their estates. The mine in question is on the demesne of Mr. Herbert, and is one of the most picturesque spots about the celebrated lake of Killarney. It is situated at the head of the Great Lake, which, being thirty-seven fathoms deep, is navigable for boats of any burthen for five miles to the head of the river Laun, a considerable stream, as broad as the Thames at Windsor; this is also navigable, though not to any useful extent, nor at all times, owing to some shallows which might easily be deepened. The fall in the ten miles to the sea is only thirty-seven feet. Castlemain Bay, the port, is a safe harbour, though there is a bar at the entrance of it. This natural navigation might be improved at no great expense, and it is so desirable for the commercial and agricultural purposes of the inhabitants of a district not only extensive, but valuable for its oak wocds as well as its mines, that it has become a national object to clear the bed of the river, and the Government having offered to defray one-third of the expense, the landed proprietors and others have agreed to raise subscriptions sufficient to carry it into execution, so that the business only requires to be set about.

The copper mine of Ross Island, in the neighbourhood of Mucrus, 
Extracts from the Minute Book of the Geological Society. 597

has revived the business of mining, in which the peasantry were formerly employed so effectually, that miners may be procured in plenty on the spot, while the local advantages of cheap and abundant markets, inexhaustible fisheries, and a low price of labour, are in that part of the kingdom peculiarly great.

Mr. Herbert made one trial only without any previous boring, and found a thin sheet of stone coal at four fathoms depth, and for the most part slate hardening into rock over the coal, so as to afford a very safe roof. The road thence to the head of water at Buleragh, or as it is better known by the name of Cloghareen, has a regular descent, except a quarter of a mile up hill; whilst the source of water at Cloghareen, formerly employed to turn tilt-hammers, water-blasts, \&c. is perpetual, and uninfluenced by any season.

The high mountains south-west of the mines are a brown, tending to blue slaty rock very dense, where cut deeply by torrents. These mountains are evidently imposed on a foundation of limestone of so fine a grain as to take a polish, and afford marbles of a great variety of colours; red and white, and green and white, are the predominant. The lake is the boundary of the two substances. The gentle ascents and bases of all the mountains, as well as the plains on every side of the mountains, are of the same limestone bursting out even at twelve miles south at the sea; but in some places varying in the level from horizontal to a dip of about $30^{\circ}$, so that there must be fractures or faults in it. This limestone is the metallic bed at Ross Mine and at Mucrus; the coal is found in the slate hills, and imposed also on the limestone.

The vein of Mucrus has been held in high estimation in every age of which tradition has preserved any accounts. Rude and laborious traces of ancient minings remain in several places, and are vulgarly, though erroneously, known by the name of Danish works. Many 
598 Extracts from the Minute Book of the Geological Society.

shafts at several miles distance have been sunk, though long since filled up, of which no history gives us any relation.

Ross vein lies parallel to Mucrus vein, at the distance of one mile and a half, and in the same bed of limestone. East of Ross Island, at Mr. Richard Herbert's, of Capirnaane, a trial has been made, and lead found (probably in Ross vein.) Lead or copper is also said to have been met with in a small island, lying midway between Capirnaane and Ross, but little is known respecting it.

There is a house remaining at the new shaft, formerly used as an assaying furnace or office.

Six years ago the new shaft remained open, and it may now be cleared at a small expense, being still dry.

The late Mr. Herbert, who had very considerable knowledge of chemistry and metallurgy, expressed his opinion in the year 1756, that if copper gave $£ 60$ per ton, the ore of the new shaft would be worth working.

1814, May 20.

Notes concerning the Geology of part of North America, lying to the west of Hudson's Bay, extracted from various papers presented to the Society by Earl Selkirk.

The following geological observations upon a part of the territory of the Hudson's Bay Company were transmitted to the Geological Society, by their late member, the Right Hon. Earl Selkirk. His lordship having at the same time presented the Society with a collection of specimens from the rocks referred to in these observations, the descriptions of all the rocks, of which specimens have been received, have been corrected by an examination of the specimens themselves. 
Extracts from the Minute Book of the Geological Society. 599

The notes concerning the rocks found on the banks of the Nelson river are extracted from the journal of Mr. W. Auld, an officer of the Hudson's Bay Company, appointed to survey the lower part of that river from York fort to Split lake. A few specimens from the same river below Split lake were obtained from Mr. Kerney, a gentleman who after visiting an Indian village on the Missouri, about the latitude $47^{\circ}$ and longitude $101^{\circ}$, descended the river Nelson from lake Winipic to York fort. A description of the few specimens which he collected on the river Nelson will be appended to the notes of Mr. Auld.

The observations on the route from York fort to Winipic, and thence to the Red river, were made by Mr. Abel Edwards, Surgeon to the Settlement on the Red river; and it is by this gentleman, and in the course of the route which he pursued, that the specimens transmitted to the Society were chiefly collected. The specimens from No. 14 to No. 27, both inclusive, were collected by Mr. Holdsworth, surgeon at York fort, and by him together with the observations that accompany them, transmitted through $\mathrm{Mr}$. Edwards to Lord Selkirk.

Notes upon Nelson River, near York Fort, Hudson's Bay, extracted from the journal of a survey made by Mr.W. Auld, July, 1812.

The high banks begin near the mouth of the Nelson river, about seven miles below Flamborough Head, being at the head about 100 feet high. They are of a light clay-colour, composed of mud and sand with a few small stones, and are of a very firm consistence, presenting every where a steep ascent, except where water has undermined them. Where this has happened, portions of the cliff have slipped down; and these are soon swept away by the strong current of the river. Opposite to the Seal Islands, Vol. V. 4 \& 


\section{Extracts from the Minute Book of the Geological Society.}

the bank cannot be less than 150 feet high. Here there appears to have been at some former time an extensive slip. The fallen mass is about twenty or thirty yards wide, and two or three hundred yards long, and when 1 observed it, was about 10 or 12 feet higher than the river, which was then much above its ordinary level. Timber grew upon this under-cliff to a pretty good size, as the earth on its surface was deeper than upon the summit of the bank, where the layer of vegetable mould was very thin.

Near the first rapid as you ascend the river the acclivity of the bank is about $60^{\circ}$; in many places the ascent is almost perpendicular; an instance of very great tenacity and consistence in a body containing a large proportion of sand with scarcely any mud. The substance of the bank, when consisting almost entirely of clay, not unfrequently assumes the appearance of stone, having the form of regular lumps, which resemble limestone. These lumps break under pressure, but in breaking preserve an angular shape, the surfaces of the fracture resembling those of limestone. Limestone is found a few feet below the clay at the bottom of the bank and in the bed of the river.

At the second rapid as you ascend the river, the portage is good, being about 100 yards in length, over flat limestone rocks, which are not more than four or five feet above the level of the water. From the head of this rapid the distance is two miles to the foot of the great limestone fall.

At the great limestone fall, the river, which is here nearly a mile broad, does not fall suddenly, but rushes with inconceivable impetuosity over the beds of limestone. We had here an opportunity, in walking over the surface of the ice, to notice the tremendous height to which the water had risen during the spring floods at these rapids, trees of various sizes lying broken down by 
Extracts from the Minute Book of the Geological Society. 601 the ice at the height of at least forty feet above the level of the river, as it stood where we observed it. There being but little depth of water in any part of the river's passage over the flat beds of limestone, these on the breaking up of the river obstruct the passage of the ice from bank to bank; which being thus collected in large masses, dams the water up. When the ice gives way, the water instantly subsides, leaving the banks covered with a thick wall of ice, which it requires the greater part of the summer to dissolve.

Eight miles above the limestone fall is a portage forty yards in length, over flat rocks of a very solid and hard texture, of a greyish brown colour. This rock now forms the bed of the river, and we no longer observe the slightest trace of limestone among the boulder-stones along the shore. Below the portage the limestone rises to the height of about ten or twelve feet above the level of the river, and consists of plates that are from two to twenty inches thick.*

As we ascend, the bank contains more sand and gravel with a

* Tbe specimens No. 17717 and 17718, Coll. Geol. Soc. brought by Mr. Kerney from this part of Nelson river, consist of black flint, much resembling the flint obtained from our chalk pits.

"The same kind of limestone," observes Mr. Auld; "is also found in Churchill river, at the distance of about fifty-six miles from the sea, extending along that river more than twenty-five miles, and rising at last for twelve miles together to the height of sixty or seventy feet above the water, while the bed of the river is composed of the same hard brown rock that we find in Nelson river. The same limestone is also found in that branch of Hayes's river which is called the Shemataway, where it is of great height, and is covered as in Churchill river, with only a thin coating of soil. It is seen again in various places upon Severn river, being first observed at the distance of about thirty miles from the sea, and extending throughout the distance of above fifty more, but in no place rising more than fifteen or eighteen feet above the water. The natives say that the same kind of stone appears in the rivers between the Albany and the Severn. At Martin's fall, upon Albany river, below Gloucester house, the same rock is said to be found not in strata but in mass, and to be a white one, much lighter in colour than the stratified rock upon the Shemataway. Upon the Seal river, which $I$ ascended eighteen years ago, I only remember that the banks adjoining two rapids were composed of laminated stone."

$$
4 \text { G } 2
$$


602 Extrarts from the Minutc Book of the Geological Society.

larger proportion of boulder-stones, rising to the height of about one hundred feet. Near the water, the clay assumes the appearance of angular masses of stone, whose surfaces appear to be washed with a red ochry matter.

At the Kettle falls, the country rises to a less considerable height above the river. The bank is now about twenty-five feet high and very sloping. The river here runs through numberless chasms formed by a multitude of rocky islands, of which the greater part are perfectly bare of vegetation, though some are covered to the top with herbage, and two or three have large trees growing in perfection upon them.* Presently afterwards the channel being narrowed suddenly, to the width of one hundred yards, a prodigious rush of water forces itself through a horrid opening in the rocks.

The portages at the Kettle falls amount together in a direct line to one-third of a mile. At the second portage we carried every thing one hundred and eighty-two yards upon the north side of an island, where numerous excavations of a circular form are seen in the solid rock. It is from the form of these excavations that the Kettle falls have received their name. The origin of these excavations may probably be traced to boulder-stones, which lodged in cavities, set in motion by the water, and aided by the attrition of sand, wear themselves thin hollow cups in the rock. The rocks upon this island consist of whinstone or granite.

Towards the upper portage the ground rises to the height of one hundred feet above the river, and is remarkably steep to the distance of one-third of a mile above the portage.

On our return, when about the middle of the river, below the great limestone fall, we observed a dry shoal two or three hundred

* No. 17719, Coll. Geol. Soc. brought by Mr. Kerney, from this part of the river, consists of hornblende slate. 
Extracts from the Minute Book of the Geological Society. $\quad 603$ yards long, composed of many hundred blocks of limestone each weighing several tons, and four feet thick or upwards, resting upon stones of a smaller size. This shoal, never having been observed before, must have been formed during the deluge of ice in the spring. It is not impossible that the next spring will entirely remove it.

Notes taken during the summer of 1812, on a journey from York Fort Hudson's Bay, to Lake Winipic and the Red River, by Mr. Abel Edwards, surgeon at the settlement on Red River; together with a description of the specimens collected by $M r$. Edwards and by $M r$. Holdsworth, surgeon at York Fort.

Hayes's River. The current uniform, compared with that of most of the other rivers between York fort and Lake Winipic. The bed stony.* The shores on both sides bold and low alternately. The soil loose and argillaceous; but in some places sandy.

Steel River. At its entrance into Hayes's river very narrow, but soon becoming wider. The colour of the water whitish, forming a striking contrast with the colour of the water of Hayes's river. The current more uniform than that of Hayes's river. The bed stony. The greatest depth of water nine feet. The shores similar in appearance to those of Hayes's river, but the soil rather more sandy.

Hill River. The current strong and interrupted. The bed stony. The shores resembling those of the two former rivers, except that where the banks are high, they are more sloped. At the first carrying place the descent of water is about eight feet perpendicular. The portage is over a bed of granite intersected by large veins of quartz running east and west.

* From Mr. Auld's observations, it seems probable that limestone forms the stony bed of this river 
$60 t$ Extracts from the Minute Book of the Geological Society.

Specimens collected upon Hill river.

No. 17720, Coll. Geol. Soc. from the second bank on the north side of Hill river, as you ascend from Hill river house. Red caicareous clay.

No. 17721, from the Sugar loaf. Slaty calcareous clay, enclosing many fragments of limestone, and having a tendency to break into rhomboidal forms. The strata of this clay rise towards the west at an angle of $80^{\circ}$. All the banks of the river from its mouth to the Sugar loaf are composed of it.

No. 17722, from the 1st. carrying place. Slaty granite, or gneiss, composed of white quartz, black mica, and flesh-coloured felspar.

No. 17723, From the same place; and forming veins in No. 1. White milky quartz, containing yellow iron pyrites.

No. 17724, from the same place. A slaty rock, consisting of quartz and mica, without any felspar.

No. 17725, from the Point-of-rock handing place. Resembles No. 4.

No. 17726, from the rocky carrying place. Black slaty hornblende rock, the hornblende being in small crystals.

No. 17727, from little rocky island. Green talc imbedded in granite.

No. 17728, from the smooth rock carrying place. Felspar forming veins.

No. 17729, from the same place. Black mica and felspar, forming veins in a small grained granite.*

* The following specimens collected by Mr. Holdsworth, or from rivers not mentioned in the route of Mr. Edwards.

No. 17730, from the lower carrying place in Jack river. Coarse grained granite, containing reddish felspar and black mica.

No. 17731, from the upper carrying place in Jack river. Granular quartz rock, con. taining black foliated mica, No. 17732. 
Extracts from the Minute Book of the Geological Society. 605

Swampy Lake. Length ten computed miles. At its entrance it is very shallow, owing to a sandy bar, which separates it from Hill river. On crossing the bar you immediately get into water from one to five fathoms deep.

Holy Lake. Length thirty miles, greatest breadth four miles. Depth of water from three to four fathoms. Colour of the water whitish. Botton sandy. In this lake are several small islands, mostly rocky.

No. 17739, from the northern side of Holy Lake, near Oxford House. Compact dark green chlorite slate.

Wippinapanish River. Course very winding. The shores more flat and rocky than those of the rivers to the east of the Holy Lake. The bed stony.

Plentiful Lake. This is a very small lake being only four miles long, and scarcely two broad.

Rabbit River. Current easy. Shores low and grassy. The bed muddy.

Side Pine Water. Extends from the Rabbit river to the Hill carrying place. Colour of the water black. The bed rocky. The coast towards the carrying place is precipitous, and composed entirely of rock.

No. 17740, from the Hill carrying place. Compact fine grained hornblende rock. A large dyke was observed at the hill

No. 17732, from the east end of Knee lake, ten miles from the entrance. Resembles potstone, but is harder and is fissile.

No. 17734, from a small island at the Knee. Oxidulous iron. The compass does not traverse on passing this island.

No. 17735, from a small island one mile beyond the Knee. Chlorite slate.

No. 17736, from the second carrying place in Trout river. Fine grained mica slate, with protuberances arising from some imbedded crystals.

No. 17737, from the Whitefall carrying place. Granite.

No. 17738, from the same place. Pinkish-coloured hornstone, with appearances of slate on the margin of the specimen. 
606 Extracts from the Minute Book of the Geological Society.

carrying place running in a perpendicular direction, and crossed by another that ran horizontally about three inches above the level of the water. Besides the dyke there were several veins, of which the largest ran south-west and north-east. Several loose stones were found here resembling No. 17722.

The places from which the two following specimens were brought are not mentioned in the route, but it is presumed that they lie near to the Hill-carrying-place.

No. 17741, from the painted stone carrying place. Greenish quartz rock. The portage is over a rock resembling No. 17722.

No. 17742, from the portage in Sea river. Gneiss with white and flesh coloured felspar.

Ecckemamis, or Little River. Very narrow and winding, and extremely shallow, containing many Beaver dams. Shores flat, resembling water meadows. The bed muddy.

Henry Lake. Length four miles, breadth one mile, water blackish and very shallow. Bottom muddy.

Playgreen Lake. This is a continuation of the great lake Winipic; and is full of islands and low rocks; greatest depth of water ten feet. The bottom muddy.

Lake Winipic. On the 14th of August, our boats entered this lake. From the first point on the western side to the first point on the eastern side, bearing south-south-east from the former, the depth of water was uniformly from three to three and a half fathoms. On the 19th of August, in going from the point above Beaver river to Blood river, we sounded with nine fathoms of line, and did not find the bottom. The water of the lake is of a whitish hue, and the buttom is composed of a mixture of sand and mud. The coast on the eastern side, until you arrive at the straits, is low and sandy; but numerous rocks lie concealed at a little distance 
Extracts from the Minute Book of the Geological Society. 607 from the land, and in many places breakers were observed to a great distance from the shore. In the strait the coasts on both sides are bold and rocky, and on the eastern coast there are numerous harbours. On the 21st of August, my lead being stolen out of the boat by some Indians, I was unable to take any more soundings.

Specimens collected upon Lake Winipic.

No. 17743, from a small rocky isle north of Blood river. Large grained granite, composed of white quartz, flesh coloured felspar and black mica. This granite is composed of larger grains than any that we found in the rivers below. It had numerous veins of quartz ramifying through it in various directions, though mostly running from north to south.

No. 17744, from the west side of the lake near Buffalo island. A greyish fine-grained rock, consisting of quartz and mica, with some carbonate of lime. The veins in this rock were large and numerous, running north-east and south-west.

Red River. On the 29th of August, our boats entered the Red river, by the largest branch, the mouth of which is narrow, and the banks on both sides of which are low and marshy, to the distance of about nine miles from the lake. The face of the country then changes, and the shores become more bold. The bed of the river is composed entirely of mud. The colour of the water is white.

The appearance of the country in the vicinity of Pembina river, is quite flat, with little wood. Vast plains extend in every direction, having nearly a level surface.

A single specimen, No. 17745, brought by Mr. Kerney from the banks of the Missouri, at the latitude and longitude above mentioned, consists of a blue compact porcellanic limestone. "There is reason to believe," observes Lord Selkirk, " that limestone extends through VoL. V. 4 H 


\section{Extracts from the Minute Book of the Geological Society.}

all the country west of Lake Winipic as far as the rocky mountains, and that there the primitive rocks reappear. On the verge of these mountains coal has been observed; but their central parts are described as being composed of very hard rock, whose beds are vertical or highly inclined. Some specimens collected in those mountains were sent home in the year 1811, and fell into the hands of Professor Jameson of Edinburgh."

\section{5, Nov. 17.}

An extract of a letter from Mr. J. Templeton, of Belfast, addressed to J. J. Berger, M. D. on the formation of peat bogs, was read.

"Your request about the plants of bogs and of their formation, I will endeavour to answer as fully as possible. My theory is, that no bog is ever formed without an abundant stock of moisture. The greatest mass of bog almost uniformly derives its origin from impediments intercepting the flow of water from a valley; a lake is thus formed; in whose waters is only nourished if in the mountain regions, the Lobelia dortmanna, and sometimes the Sparganium natans with a few straggling stunted plants of Scirpus lacustris. If in the lowlands a greater variety appear, we may observe the curious "Conferva echinulata," floating like powdered verdigris; immersed at even great depths grow Sponges, the Charæ, the Ceratophylli with numerous Confervæ, and around the shores gradually approaching the centre; as their annual decay lessens the depth of water, we find various species of Potamogeton, the Nymphæa alba, N. lutea, the Lobelia dortmanna (if the shore is composed of sand or small gravel.) Polygonum amphibium, Sparganium natans, Scirpus lacustris, Arundo phragmites, Typha latifolia, Schœnus mariscus, Menyanthes bisfoliata, Alisma plantago, Phellandisum aquaticum, Sparganium simplex, S. ramosum, Cicuta 
Extracts from the Minute Book of the Geological S'cieity. 609 virosa, Sium latifolium, S. nodiflorum, Butomus umbellatus, Sisymbrium nasturtium, S. amphibium, Enanthe crocata, EEfistulosa, Scirpus palustris, S. fluitans, Stottonia palustris, Hydrocharis morsus ranæ, Sagittaria sagittifolia, Ranunculus aquatilis, R. fluviatilis, R. hederaceus, Carex paludosa, C. ampullacea, C. acuta ; R. aquaticus; To these plants succeed those which require to have themselves altogether uncovered with the water, or their roots fixed in a watery or soft mud, as the Sphagnum latifolium, S. cuspidatum, S. capillifolium, S. squarrosum; Dicranum glaucum, D. flexuosum, Hypnum cuspidatum, $H$. stellatum, $H$. nigrosum, $H$. scorpioides. H. revolvens, $H$. aduncum, H. palustre; Polytrichum commune; among these mosses grow Vaccinium oxycoccos, Andromeda polifolia, Drosera longifolia, D. anglica, D. rotundifolia, Schœnus albus, Scirpus multicaulis, S. cœspitosus, Eriophorum angustifolium, E. vaginatum, Narthicia ossifraga, Erica tetralix; when the bog rises higher, and is somewhat drier, Erica vulgaris, E. cinerea Myrica gale, Vaccinium myrtillus, Empetrum nigrum appear (especially on high or rising grounds) with Eriophorum vaginatum, Nardus striceta, Agrostis alba, A. vulgaris, Melica cærulea, Montia fontana, Vaccinium vitis idæa, Menzieria polifolia (Erica Daboocia) Pyrola media, P. minor, Juniperus communis, J. procumbens, Ulex nanus, Salix prostrata, S. fusca, S. repens, S. argentea, Carex pilulifera, C. binervis, C. recurva; and united with these in great quantities, Trichostomum lanuginosum, Dicranum flexuosum, Polytrichum commune, Bartramia arcuata, Hypnum splendens, H. loreum, $\mathrm{H}$. cupressiforme and $\mathrm{H}$. molluscum. When these plants vegetate luxuriantly, the bog rises rapidly, and the formation of the best kind of peat is accomplished, very different in consistence from that formed by the deposit of the mere aquatics, which partake of a clayey or saponaceous texture, and although they give a strong 4 н 2 


\section{Extracts from the Minute Book of the Geological Society.}

heat they do not kindle so freely as this more spongy kind. The following plants occupy our moist grounds, but can scarcely be said to administer to the formation of bog; Pinguicula vulgaris, Triglochin palustra, Schœnus nigricans, Mentha aquatica, M. hirsuta, Lycopus Europœus, Centunculus minimus, Iris pseudo acorus, Gallium uliginosum, G. palustre, Rumex aquaticus, R. acutus, Myosotis palustris, Parnassia palustris, Anagallis tenella, Hydrocotyle vulgaris, Juncus effusus, J. buffonius, J. conglomeratus, J. lampocarpus, J. acutiflorus, Alisma ranunculoides, Polygonum amphibium, P. hydropiper, P. minus, Stellaria uliginosa, Comarum palustre, Ranunculus flammula, R. lingua, Sium verticillatum, Scrophularia aquatica, Sisymbrium sylvestre, Hypericum elodes, Carex riparia, C. cæspitosa, C. vesiearia, C. davalliana, C. pulicaris, C. stellulata, C. curta, C. divisa, C. muricata, C. paniculata, C. æderia, C. flava, C. pilosa; Scutellaria galericulata, Pedicularis palustris, Viola palustris, Malaxis paludosa, Orchis latifelia, Carduus palustris, Gnaphalium uliginosum, Senecio aquaticus.

I conceive that the peat or mossy stratum formed on the tops of mountains is nourished by the mists condensed on their tops; and that the bogs in a valley not immediately produced around or by a lake, are formed in the first place by musci intercepting the flow of water from a spring, and generating that spongy soil on which the second class of plants grow; this kind of bog in many of our valleys may be seen to rise considerably higher in the middle than when the water is allowed to percolate more freely through the substance, and flow off whenever drains are cut into this bog, when its increase is stopped and a very great depression mostly takes place. The surface is then apparently converted into a soil fit for the husbandman to begin to work upon; but all those who have speculated on this soil, have soon found that without great expense for manure the productiveness soon failed and disappointed their hopes." 
Extracts from the Minute Book of the Geological Society. 611 1816, June 21.

A notice respecting the discovery of some fossil bones was read. It was contained in a letter from Robert Anstice, Esq. M.G.s. of Bridgewater in the county of Somerset, addressed to the late Francis Horner, Esq. M.P.

1. Bones (belonging apparently to the great animal discovered at Lyme) have been found in a quarry of lias, at the distance of a quarter of a mile E.N.E. of Kingsdon, between Somerton and Ilchester, in the county of Somerset.

2. A molar tooth of an elephant, and some large bones, have been found in an alluvial soil adjoining the bridge over the river Yeo, at Yeovil, in the same county.

3. A fish, which appears to belong to the genus Clupia, and resembling Clupia alosa, has been found in lias at East Quantockhead, about 18 feet under ground, above high water mark.

4. Teeth of some unknown carnivorous animal have been found in the water course of a peat moor, in the parish of Calcott, between Bridgewater and Glastonbury.

1816, Nov. 15.

A notice from James Sowerby, Esq. M.G.s. on fossil organic remains found on the bank of the Tagus near Lisbon, was read.

These remains are, an Ostrea similar to the $O$. virginea Linn. a Mactra, the cast of a large Serpula, and other shells which bear a great resemblance to those found in the Calcaire grossière of the basin of Paris.

\section{7, April 18.}

A letter was read, from Dr. Meade to Mr. Vaughan, relating to a slab of serpentine from North America.

The quarry whence the slab was obtained was situated near the 


\section{Extracts from the Minute Book of the Geological Society.}

town of Milford, in Connecticut. It is a serpentine rock. The whole country in the neighbourhood is of a primitive formation, consisting principally of gneiss and granite alternating with primitive limestone. A stratum of the serpentine, several yards wide, runs between the limestone. It extends for several miles, accompanied with asbestos, amianthus, and diallage. The quarry is extensively worked.

The serpentine has considerable resemblance to the vert antique; the green parts, which are the most abundant, are of serpentine. Veins of white calcareous spar run through it, and also black pieces of chromate of iron. From this latter circumstance, Dr. Meade is induced to think, that all the noble or green serpentines are coloured by the green oxide of chrome.

\section{7, May 16.}

An extract of a letter was read, from Mr. John Hanton of Lickbey in the Rosses, addressed to T. F. Berger, M.D. giving an account of the effects of the Storm of Dec. 4, 1811, in which the Saldanher was lost in Lough Swilly.

"I have made very particular enquiry relative to the kind of fish cast out by the storm of the 4th of last December on this coast, and the circumstances attendant thereon. On the shores of the isle Anasmor, lobsters, craw-fish, sea carp (called in Irish ballan) ling, heach, glamin, whiting, haddock, sprat, cod, and pollock, were cast on shore. On the shores of the main land, all the above kinds (except lobsters and craw-fish) with the addition of eels large and small, and a brown kind of fish about fourteen inches long, never before noticed here, with a large head and small body, supposed a mullet. The maws and gills of all were quite filled with sand, whence it would appear that from the furious 
Extracts from the Minute Book of the Geological Society. 613 agitation of the sea, the sand became so blended with it, that the fish were suffocated. No flat-fish were found dead; the greatest quantity of fish were found in shallow sandy bays : such effects have not occurred in the memory of the oldest man now living.

"We may judge of the uncommon depth to which the agitation of the sea reached during that storm, from the known depth at which the above sorts of fishes are generally caught; thus eels are fished in fifteen fathoms, and cod in from twenty to thirty fathoms; but it appears that at the approach of a storm, fishes of any kind go before it, passing into less deep water than they use to live in. It is admitted that the agitation of the sea in the most violent storms does not usually penetrate to more than seven feet deep."

\section{7, Nov. 21.}

An extract of a letter from Robert Austin, Esq. M. G. s. of Bridgewater, was read; it was accompanied by a specimen of coralloidal arragonite.

"You are aware that the chief material of the Quantock Hills in this county is grauwacke, and that they are penetrated through a great part of their length by a vein of mountain limestone. In a quarry, situate six miles to the west-south-west of Bridgewater, near the village of Merridge, is a fissure in this limestone rock, which for a few years past has been famous for producing calcareous stalactites and stalagmites of considerable beauty, but not very essentially different from those produced in many limestone caverns of this and other countries; this fissure has lately been somewhat cleared and explored to a greater extent than before.

"I visited this place about three weeks since, and after working my way in the fissure of the limestone to the distance of about forty yards from the entrance, I found the passage there so contracted, 


\section{Extracts from the Minute Book of the Geological Society.}

I could not proceed further until it was enlarged, when it opened into a cavern in the grauwacke, of perhaps twenty yards in length, six to ten yards in breadth, and from three to six feet in height towards the middle: the roof, forming an irregular arch, running down to the floor on each side. About one-third of the surface of this roof I found studded and frosted over in patches with stalactites of coralloidal arragonite, the branches of which extended to a great length in all directions, in straight and variously curved lines. The cause of the difference observable between the common calcareous stalactites of the outer fissure and those of the inner cavern, which consist of coralloidal arragonite only, appears to me worthy of investigation.

"The fissures and cavern are kept in a constant state of humidity by water penetrating through the superincumbent ground, which is but a few yards in depth. The vapour arising from this in the cavern is considerable, and I am informed, often appears issuing from the mouth of the fissure in cold weather."

\section{8, January 2.}

An extract of a letter from Capt. D. Carmichael, F. L. s. on the geological structure of part of the Cape of Good Hope, was read.

"The Table mountain and the Lion's head rest upon a base of granite; Green-point, Table valley, and the Devil's hill, on a base of schistus, of which the whole of the Lion's back is likewise composed. The granite extends up to the rocky crown of the Lion's head, an elevation of nearly 1500 feet; and the declivity of the mountain is strewed with enormous masses of it, rounded by successive exfoliations, and entirely detached from the soil. On the side of the Table mountain, the space on which the granite is visible is contracted to about 500 feet, and occupies the centre of the declivity. 
Extracts from the Minute Book of the Geological Society. 615

At the spot called Sea Point, the waves have washed away all the loose earth, and left the rock exposed for a considerable extent. Here the granite and the schistus come in contact, and the manner in which their union has been accomplished it would be difficult to explain on any known theory of geology. In the space of 200 yards along the shore, the reef is a chaotic mixture of these two rocks, each predominating in the mass as you approach its respective side, where it is pure and unmixed. In some parts they form alternate layers of various diameter; in others, fragments of the schistus of all figures and sizes lie imbedded in the granite, which appears to have pervaded their minutest fissures. Between this mixed mass, however, and the pure schistus, there is interposed a rampart of granite, apparently different from the common sort, which, for about 200 yards is uncontaminated; but as it approaches the schistus, becomes mingled with it in the same manner as the granite. From this to Green Point, and extending through Bobben Island, a distance of about twelve miles; the schistus is pure, and stands in strata approaching within a few degrees of a vertical position, inclining in some parts to the eastward, in others to the opposite point.

Close to the path which leads from Cape town to the summit of the Table mountain, there runs a stream, which, at the point where the granite and the schistus meet, has carried off the superincumbent earth, and exposed the surface of the rock from ten to twenty yards in diameter, and about 200 yards in length, sinking at an angle of about thirty degrees. Along the whole of this space the schistus is intersected by veins of granite, varying from three feet in diameter to as many lines. These veins branch off in all directions, some straight, others twisted into the most fantastic convolutions. In the face of the rampart which borders the channel on each side, the Vor. V. 


\section{Extracts from the Minute Book of the Geological Society:}

veins are equally conspicuous. But here they, as well as the schistus, are in a state of disintegration, and crumble under the pressure of the layers.

In walking along the shore from Campo Bay to Sea Point, you meet with numerous veins of basalt in the granite, varying in diameter from an inch to ten feet, and branching in as many directions as those of the granite with schistus. Here also you will frequently meet with detached blocks of schistus imbedded in the granite.

The sandstone which forms the upper part of the Table mountain, Lion's head, and Devil's hill, lies in horizontal strata, intersected by vertical fissures. It is of a siliceous nature, and encloses rounded nodules of quartz."

1818, June 19.

A notice was read concerning volcanic chromate of iron. By Henry Warburton, Esq. M. G. s.

The author, on presenting to the Society a specimen from the extinct volcanoes of Hildesheim in the ci-devant department of the Kyll, consisting of granular peridot, coloured emerald-green by Chrome, and enveloping minute grains of chromate of iron, takes occasion to remark that the metal chrome has not hitherto been enumerated amongst the matters ejected by volcanoes. On the presumption of chrome being excluded from volcanic matters, M. Sementini, professor of chemistry at Rome, has founded an argument, by which he endeavours to prove that a red earth, which fell in Calabria* during a storm, is of meteoric origin. Having detected chrome in this earth, this metal, he argues, being an ingredient of meteoric but not of

\footnotetext{
* Journal de Physique. March 1818.
} 
Extracts from the Minute Book of the Geological Society. 617 volcanic bodies, the earth is probably of meteoric nature. The specimen, however, from Hildesheim, destroys the grounds of this reasoning; and it is most probable that the earth from Calabria, since it contains crystals of pyroxene, is volcanic.

\section{8, Dec. 4.}

A letter from Edward L. Irton, Esq. was read, containing some further information respecting one of the vitreous tubes found at Drigg in Cumberland, an account of which was inserted in the 2d volume.

"The remains of the third sand tube at Drigg have been discovered. Within the two first feet, we passed that bed of pebbles which (as has been formerly stated), diverted the direction of the tube. Following it downwards, within two feet more we came to a bed of smaller ones, closely bedded in wet sand; through this the electric matter had apparently penetrated with difficulty, but with great force, as it adhered with strong vitreous firmness to every little pebble of the size of a kidney-bean or less that stood in its way. Its course through this wet sand was extended to the depth of nearly eight feet, when the tube became so very contorted and twisted in its course by the different pebbles it met with, as to assume a very different appearance. It passed two pebbles without adhering to either, though it was much flattened and compressed in its formation; more so than what you observed in the specimens you procured when here. In one instance it had the usual tubular appearance, but at the distance of eight or nine inches: was completely solid without any central perforation; though on continuing its course lower down it again assumed the rugged and tubular shape.

"I have one or two specimens of a very singular conformation, 


\section{Extracts from the Minute Book of the Geological Society.}

where the perfect tube of half an inch diameter, meeting with a bed of pebbles of the size of kidney-beans, has dispersed and spread its agglutinating power, so as to form a mass of two and a half-inches in diameter, and in which the vitreous matter visibly surrounds each particle. In the course, however, of two or three inches more, it again assumes, on the opposite side of the mass, its usual tubular shape, and continues till it again meets with other obstacles.

"In its course about three feet from the surface, it had made an attempt to pass between two large pebbles about three-quarters of an inch asunder, by which effort it was much flattened, and its diameter much reduced; each pebble was partially vitrified, but no adhesion had taken place.

"After that, for four or five inches, though going through soft sand, it became much contorted, as fig. 1. pl. 39. The lower the tube went, the more it seemed inclined to produce ramifications, some of such minute smallness, as not to be handled without breaking, but yet more perfect tubes than the large ones. One specimen $\mathrm{I}$ have is formed, as in fig. 2. pl. 39, from a ramification only: the diameter of this complete little tube is not more than one-eighth of an inch, and its length about two inches.

"In its descent downwards, and at the depth of about six feet, it branched off in various directions, as in fig. 3. pl. 39. We followed the branch with minute accuracy, and the base terminated on a granite pebble, though not adhering to it, with a small ramification extending only a few inches. The diameter of the base of the tube, when it struck the pebble, was about one-quarter of an inch."

Note by the Editor.

As the former notice respecting these tubes had not been accompanied by an engraving, the present opportunity has been embraced of giving figures of some of the specimens in the Museum of the Geological Society. Fig. 4. Plate 39 represents about one-half in length of the largest specimen drawn of the natural size. Fig. 5 is one that is forked; and fig. $6,7,8 \& 9$ exhibit sections of various tubes. 
Extracts from the Minute Book of the Geological Society. 619

\section{9, April 2.}

An account of the Limestone of Plymouth, by the Rev. Richard Hennah, Chaplain to the Garrison of Plymouth, was read.

The bed of limestone which occupies that part of the vicinity of Plymouth that lies toward the sea, between the æstuaries of the Plym and Tamar, rises to an elevation of about 100 feet above highwater mark, as appears from an accurate measurement of the Hoe, a hill sufficiently central to afford a fair criterion of the general height of the adjoining eminences. The limestone dips towards the south or south-west, and runs in a direction nearly east and west. Its breadth from north to south does not exceed the distance of from a half to a quarter of a mile. Its length from east to west extends to many miles.

Towards its western extremity in the Dock-yard, and at the Devil's Point, we perceive it sinking into the sea; it re-appears, though only for a little space, below Mount Edgecombe, and behind the passage-house at Cremhill ferry; after which I do not apprehend that it is any where visible towards the west, except in a few confined patches or rocks. From the Dock-yard, eastward, its course may be observed uninterruptedly as far as the Plym, and across that river into the parish of Plymstock, from whence it may be traced, appearing occasionally, to a considerable distance.

The limestone, wherever I have been able to observe its contact with the rock beneath it, rests upon clay-slate. The calcarecus strata adjoining the north side of the road over Stonehouse-hill, immediately before arriving at the quarries and lime-kiln at Mill Bay, are interrupted in a remarkable manner by the clay-slate which is protruded upwards through the limestone. 
The colour of the limestone is various, though the prevailing one is light-blue, or grey, changing at times to dark-blue or nearly black, these again being marbled with infinitely various tints of red and other colours. This variety of colours, and the high polish which the stone is capable of receiving from its hard and closegrained texture, render it an article of some importance as a marble for the manufactory of siabs and chimney-pieces. The foot pavements also in the three towns of Plymouth, Stonehouse, and Dock, and their environs, are almost all formed of blocks from the limestone quarries, and it is in these pavements, after a shower of rain, that the beauty of our marble may best be observed.

Until within a recent period, it was a question whether the limestone of Plymouth contained any animal remains: the account of my having discovered these bodies in our rocks has been inscrted in the 4th volume of the Society's Transactions. The accuracy of my former statements, however, having been called in question, I can now affirm that the proofs of the presence of organic remains in our limestone, are abundant and indisputable; and so generally indeed do these remains pervade almost every part of our limestone, that I can only wonder that they have remained so long unnoticed. Visible traces of them meet us at every step, and there is hardly a hill or quarry where they do not obtrude themselves to the view of the curious. They consist of madrepores, tubipores, millepores, corals, entrochi, and various univalve and bivalve shells, among which are the anomia terebratula, and producta.

The madrepores are not confined to any particular stratum in our limestone, but are discoverable in almost every part of it, although they are variable in their quantity, being sometimes not very distinctly visible, and at other times occurring in extensive masses or layers. The other animal remains are not diffused so 
Extracts from the Minute Book of the Geological Society. $\quad 621$ generally or so plentifully, each of the remaining genera appearing to occupy a separate stratum; so that, even with regard to shells, I have not found the univalves and bivalves mixed together, but severally occupying strata peculiar to themselves. Thus it will be seen, that in the Dock-yard, on the western side of Mount Wise, at Sandy Cove, and in Catdown, bivalves retaining much of their shelly character prevail; while on the south-western side of Stonehouse-hill, at the eastern end of Mount Wise, or the eastern Hoe under the citadel, and at the quarry on the eastern side of Catdown, the shells are univalves, whose substance partakes of the nature of the surrounding matter.

I now proceed to mention the particular spots where organic remains are to be found, beginning with the western extremity of the limestone, and advancing towards the eastern.

At the distance of about 150 yards to the east of the Devil's Point, on the south side, we find, in situ, a marble of a most striking appearance, composed of stellated madrepores, of an almost pure white colour, imbedded in a blood-red matrix. Stellated madrepores, and the vertebral columns of encrini, are to be met with in that hill in greater perfection than at any other place in this neighbourhood.

In the Dock-yard I have obtained entrochi, corallites, and bivalve shells, retaining much of their shelly character; there are also many imperfect fragments of other animal remains, of which I am not able to give the names.

On the western side of Mount Wise I have frequently met with bivalve shells, retaining also their shelly appearance, together with great quantities of madrepores, columns of the encrinus, and fragments of other animal bodies, and among these an orthoceratite. 
622 Extracts from tbe Minute Book of the Geological Society.

Shells, which I believe are univalves, may be seen without difficulty in a part of the rock of Mount Wise that is uncovered, a little to the east of the battery, not far from the path-way that leads from the port-admiral's house to the navy stairs below. These shells are of a harder texture than the shells before noticed, and retain less of their natural appearance. The contents of this part of the hill resemble those of the south-western part of Stonehouse-hill, which we shall next describe.

Immediately on passing the last houses leading from Stonehouse to Plymouth, over the hill by the south side, I have found above and below the road, detached fragments, lying several feet under the present surface, differing but little from the solid rocks near them, containing, besides madrepores, many species of univalve shells so blended with the surrounding matter, as to form a solid mass, so that it has been with difficulty that I have obtained from these fragments any perfect specimens of shells. This stone is of a dark colour, and is capable of receiving a fine polish, by which its shells and madrepores are rendered beautifully distinct.

I have lately observed the presence of madrepores, entrochi, and shells, in the limestone raised from several pits opened on the north side of Stonehouse-hill for building the houses in Union-street, leading from Stonehouse to Plymouth. Madrepores and entrochi are contained in considerable quantity in masses of blue and grey limestone mixed with clay-slate, raised from a well at the back of the same houses.

At Mill Bay and Sandy Cove, which connect the west Hoe with Stonehouse-hill, the madrepores, tubipores, millepores, entrochi, corals, and bivalve shells are in great abundance, and are visible at almost every step: particularly where the limestone and clay-slate join, and are intimately blended or alternate with one another. 
Extracts from the Minute Book of the Geological Society. $\quad 623$

At Mill Bay, behind the coke-kiln, madrepores are abundant from the surface to the lowest part of the rock that can be seen.

Not far from Sandy Cove, upon the east Hoe, nearly under the citadel, I have obtained shells that are all univalves. In texture they are close-grained, hard, compact, and of the colour and substance of the surrounding matter, much resembling in their appearance those from Stonehouse-hill.

Immediately on crossing the water from the Victualling-office point, adjoining the citadel, to Tate's Hill and Queen Anne's Battery, an abundance of animal remains, although no shells, appear, particularly at the latter place. At Queen Anne's Battery, besides entrochi and many varieties of madrepores, I have observed what I conceive may be an alcyonium.

At a little distance from hence, in Deadman's Bay, near the quarry, madrepores, tubipores, and bivalve shells, with other organic remains are to be seen; and in a quarry on the opposite side of Catdown, across the road to the eastward, madrepores, tubipores, and univalve shells are found. Advancing still to the eastward as far as Prince rock and the Flying bridge, I there find entrochi, madrepores, and a fossil, of which I have collected fine specimens, and which I believe to be an orthoceratite.

Thus from the Tamar to the Plym, over a distance of nearly three miles, animal remains pervade the whole bed of the Plymouth limestone.

With regard to metallic veins, the limestone appears to be entirely free from them; for I have never heard that any symptoms of one were ever discovered in any of the quarries that have hitherto been opened. Indications of the presence of iron and manganese may occasionally be detected, serving as colouring matter, in particular spots; but these metals are always thinly spread, and are never Vol. V. $4 \mathrm{~K}$ 
624 Extracts from the Minute Book of the Geological Society.

found in any quantity. I have observed spots of pyrites in fragments of limestone taken out of a well behind the houses on the south side of Union street, Stonehouse; and among the fragments of rock raised from the solid ground in a new well on the north side of the same street, I have found specimens of limestone and slate containing animal remains and pyrites blended together.

Quartz occurs mixed with the limestone in some large fragments near the wall at the western end of Mount-wise, and also in some of the rocks forming the cliffs to the eastward of the Devil's point ; but these instances are rare, and the quartz is small in quantity.

The caves which occur in the limestone of Plymouth afford stalactitical concretions in great variety of form, and in considerable abundance. Numerous forms of crystallized calcareous spar are also to be met with in our district, among which may be enumerated the primitive and inverse rhomboids, and an acute rhomboid, the hexagonal prism, and an acute dodecahedron in the greatest perfection. Some fragments of crystals, which I possess, are beautifully transparent, and of unusual size; but such specimens are not common, and are now difficult to be procured.

\section{1, March 2.}

A letter from James Vine, Esq. Treas. G. s. was read, containing a notice on a method of hardening gypsum, lately discovered. It appears that if gypseous alabaster be heated considerably, and then immerged in water, it acquires a degree of hardness so great as to admit of a polish like marble, and may then be used for making slabs, and for other œconomical purposes. 

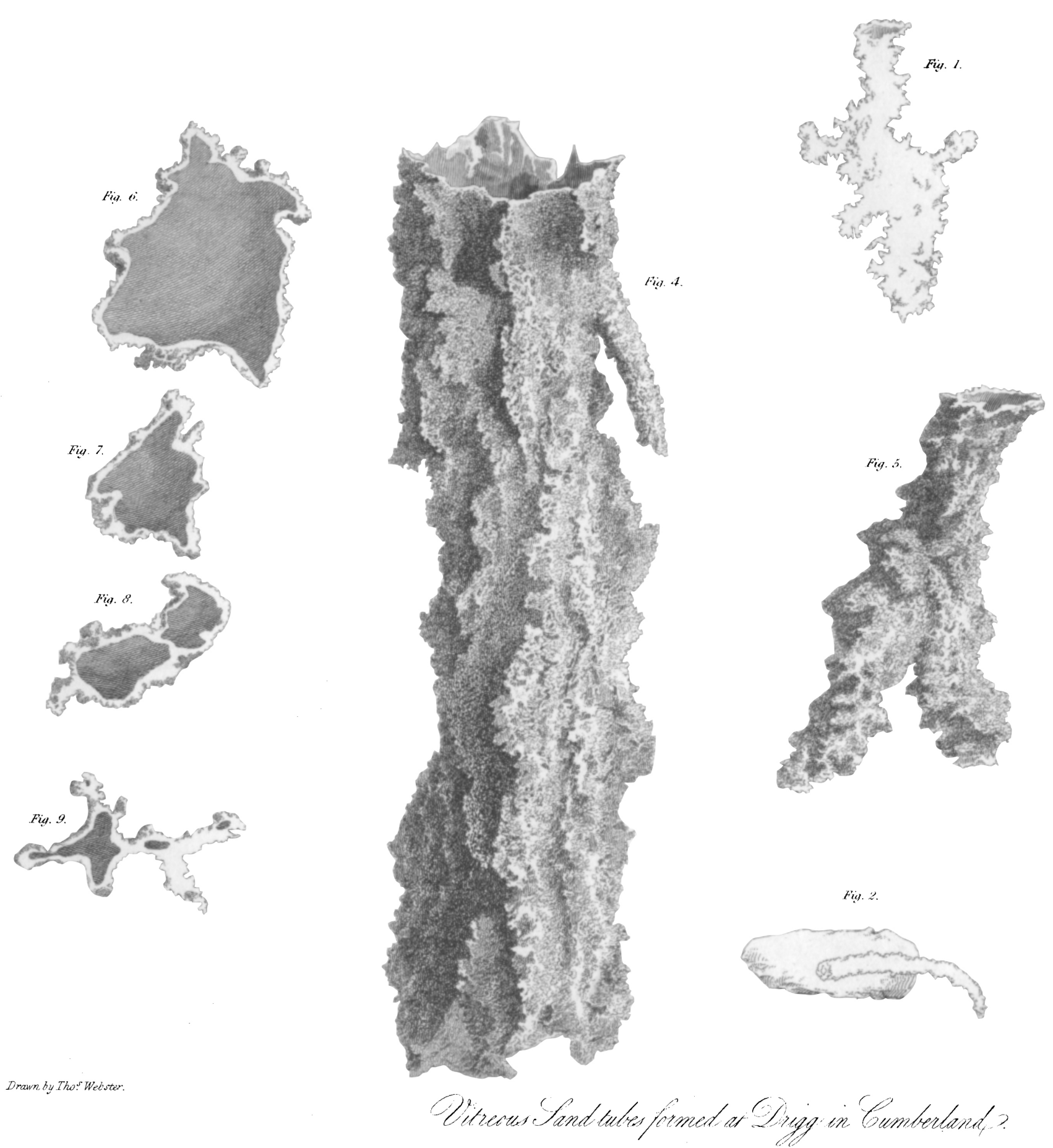

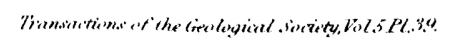

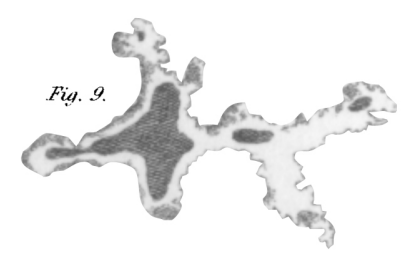

Dram by Tho: Webster.

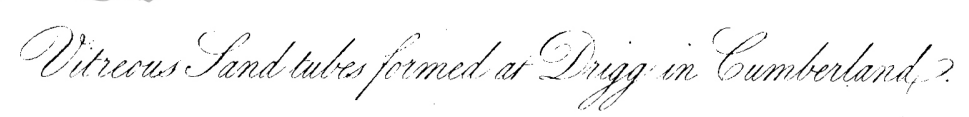

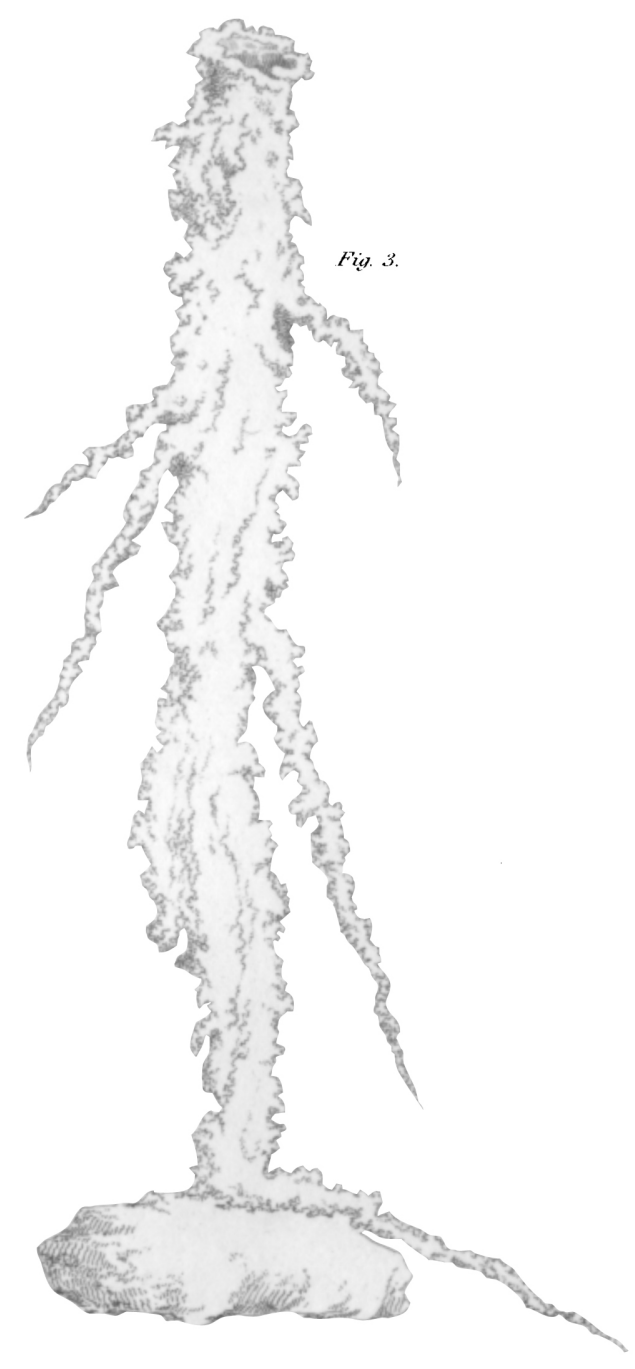

